九州大学学術情報リポジトリ

Kyushu University Institutional Repository

\title{
A Revision of the Subgenus Tarsandrena of the Genus Andrena of Eastern Asia (Hymenoptera, Andrenidae)
}

$\mathrm{Xu}$, Huan- $\mathrm{i}$

Tadauchi, Osamu

https://doi.org/10.5109/2632

出版情報: ESAKIA. 39，pp.31-46，1999-03-31. Entomological Laboratory，Faculty of Agriculture， Kyushu University

バージョン :

権利関係 : 


\title{
A Revision of the Subgenus Tarsandrena of the Genus Andrena of Eastern Asia (Hymenoptera, Andrenidae) ${ }^{1) 2 \text { ) }}$
}

\author{
Huan-li XU and Osamu TADAUCHI \\ Entomological Laboratory, Faculty of Agriculture, \\ Kyushu University, Fukuoka, 812-8581 Japan
}

\begin{abstract}
East Asian species of the subgenus Tarsandrena of the genus Andrena are revised, and 6 species are recognized from China and Mongolia. Three new species, Andrena (Tarsandrena) truncatella, A. (Tarsandrena) niveimonticola, A. (Tarsandrena) shawanensisare described. Three species, A. ehnbergi Morawitz, A. tarsata baicalensis Cockerell and A. angarensis Cockerell are newly recorded from China.

Key words: taxonomy, Hymenoptera, Andrenidae, Andrena, Tarsandrena, eastern Asia, new species, revision.
\end{abstract}

\section{Introduction}

The Palearctic subgenusTarsandrena of the genus Andrena was defined by Osytshnjuk in 1984, and 4 species were allocated in this subgenus. The nominate type species Andrena tarsata Nylander was formerly placed in the subgenus Poliandrena by Warncke in 1968, but the species of the subgenusPoliandrena are easily separated from the species of the subgenusTarsandrena by the ill-defined propodeal enclosure and broadened posterior spur of hind tibiae in female. In the present study, we recognized 6 species of this subgenus from China and Mongolia including 3 new species. The types will be deposited in the Institute of Zoology, Academia Sinica, Beijing, and some paratypes are also deposited in the Entomological Laboratory, Kyushu University, Fukuoka.

\section{Subgenus Tarsandrena Osytshnjuk}

Subgenus Tarsandrena Osytshnjuk, 1984, Vestn. Zool., (2): 24. Type-species: Andrena tarsata Nylander, 1848 , by original designation.

Diagnosis: Medium-sized bees; facial quadrangle broader than long or about quadrate; facial fovea close to inner margin of eye, various; mandible bidentate or tridentate in female; process of labrum convex, truncate; galea short, spear-shaped, outer

1) Contribution from the Entomological Laboratory, Faculty of Agriculture, Kyushu University, Fukuoka (Ser. 5, No. 25).

2) Results from the China-Japan Co-operative Study on "Studies on Systematics, Evolution and Biogeography of Asian Andrena (Hym., Apoidea, Andrenidae) No. 8. 
margin with apical third concave; maxillary and labial palpi normal; pronotum with humeral angle and ridge or lacking; propodeal corbicula well developed; propodeal enclosure well defined by lateral sutures; dorsal face outlined by raised ridges along sutures; hind tibia cuneate with extremely short scopal hairs; metasomal terga with hair bands. Male clypeus yellowish white; occasionally lower paraocular area maculae; flagellar segments as in female, FL1 longer than or equal to FL2+3; sternum 6 flat apically.

\section{Key to species of the subgenus Tarsandrena in eastern Asia}

\section{Female}

1. Length 11-13 mm; metasomal terga densely essellate with tight minute PP, terga 1-4 with complete white hair bands; [mesoscutum with strongly crowded PP, dull roughened; clypeus with distinct median impunctate space]

- Length less than $11 \mathrm{~mm}$; metasomal terga 2-4 with white hair bands, complete

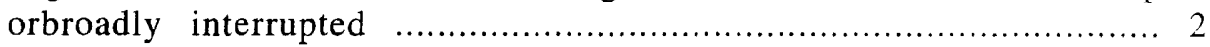

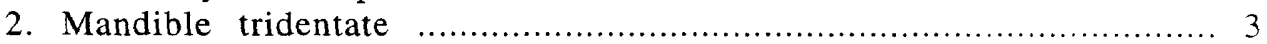

- Mandible bidentate ........................................................ 5

3. Facial fovea sharply narrowing below; clypeus coarsely punctate, strongly roughened; terga 2-4 with interrupted hair bands; [hairs on body scanty]

truncatella n. sp.

- Facial fovea not narrowing below; clypeus not roughened; terga 2-4 with complete hair bands ........................................................... 4

4. Pronotum with distinct humeral angle and ridge; clypeus with large crowded PP, median impunctate line obscure; metasomal terga with distinct crowded PP

$$
\text { shawanensis n. sp. }
$$

- Pronotum with weak humeral angle and ridge crossed by depressed sutures; clypeus with small crowded PP, median impunctate space obvious; metasomal terga with weak, sparse PP tarsata baicalensis Cockerell

5. Clypeus with broad, polished median impunctate space; mesoscutum finely tessellate with weak and sparse minute PP; dorsal propodeal face densely tessellate, not roughened; metasomal terga with weak, sparse minute $\mathrm{PP}$.... niveimonticola $\mathrm{n}$. $\mathrm{sp}$.

- Clypeus with crowded large PP without median impunctate line; mesoscutum and metasomal terga with distinct close PP; dorsal propodeal face roughened

angarensis Cockerell

\section{Male}

1. Clypeus and lower paraocular area yellow; hairs on body uniform, whitish; [flagellar segment 1 equal to the next two segments together] angarensis Cockerell

- Clypeus yellow and lower paraocular area with small yellow maculae or not; hairs on body various

2. Pronotum without humeral angle and ridge; metasomal terga with weak, scattered microscopic PP, irregular in distribution niveimonticola n. sp. 
- Pronotum with distinct or weak humeral angle and ridge; metasomal terga with distinct PP, dense or sparse .............................................. 3

3. Length $11 \mathrm{~mm}$; metasomal terga 1-4 with complete white hair bands with large and rather close $P P$ ehnbergi Morawitz

- Length less $10 \mathrm{~mm}$; metasomal terga 2-4 with interrupted hair bands with smaller and sparser PP.

4. Hairs on clypeus fulvous; humeral angle and ridge distinct, crossing by deeply de pressed sutures; dorsal propodeal face coarsely roughened .........truncatella $\mathrm{n}$. sp.

- Hairs on clypeus whitish; humeral angle and ridge weak; dorsal propodeal face densely tessellate, not roughened.

5. Propodeal enclosure with longitudinal rugulae; metasomal terga densely punctate, IS $<0.5$ shawanensis $\mathrm{n}$. sp.

- Propodeal enclosure weakly shagreened; metasomal terga with sparse PP; IS =1-2 tarsata baicalensis Cockerell

\section{Andrena (Tarsandrena) ehnbergi Morawitz}

Andrena ehnbergi Morawitz, 1888, Horae Soc. Ent. Ross., 22: 238-239 [female, middle Siberia of Russia].

Andrena (Tarsandrena) ehnbergi: Osytshnjuk, 1984, Vestn. Zool., (2): 28-29 [female \& male]; Osytshnjuk, 1995, Key Ins. Rus. Far East Six Vol., 4 (1): 510,517 [female \& male, in key].

Female: BL 11.0-13.0 mm, WL 8.5-10.5 mm $(\mathrm{n}=8)$.

Color: Flagellum reddish brown beneath; mandible with apical third reddened; wing membranes subhyaline, veins and pterostigma reddish brown; tibial spurs yellowish: posterior depressions of metasomal terga dark reddish brown.

Pubescence: Hairs on head and thorax dense, white to fulvous; those on clypeus about $400 \mu$, white; those on vertex $600 \mu$, fulvous; those on genal area white; facial fovea yellowish brown above, white below. Hairs on mesoscutum and scutellum 500-600 $\mu$, fulvous; those on mesepisternum $750 \mu$, white; propodeal corbicula well developed, white mixed with a little brown, internal hairs simple; trochanteral floccus perfect, whitish; femoral floccus dense; tibial scopal hairs extremely short, simple, whitish below. bright brown above. Hairs on metasomal terga extremely short, brown, whitish laterally except tergum 1 with long whitish hairs; terga 1-4 with complete white hair bands: caudal fimbria brown, white laterally; sterna $2-5$ with white subapical fimbriae.

Structure: Head: HL/HW = 0.75. HW:MsW:MtW $=4.0: 3.7: 4.0$. Vertex shagreening with crowded PP. OOD:POD:OCD $=0.7: 0.5: 0.4$ FL1 $>$ FL2+3. FL2 $=$ FL3 broader than long. Eyes with inner margins subparalleled. Facial fovea extending below a line at lower margins of antennal fossae, narrow, deeply depressed, separated from inner margin of eye by smooth space, $F V L=1.3 \mathrm{~mm}, \mathrm{FVW}=0.4 \mathrm{~mm}$. Face above antennal fossae with longitudinal striates, interrugal space with coarse PP, dull shagreened. Facial quadrangle slightly broader than long (about $2.7: 2.5$ ). Clypeus finely convex, surface with crowded PP, $\varnothing 20 \mu$, IS $<0.1$, dull roughened, with median longitudinal impunctate space, weakly tessellate, $\mathrm{CPL}=1.2 \mathrm{~mm}$. Process of labrum 
large, deeply truncate with rounded apical margin. Mandible bidentate. Lower paraocular area shagreening with crowded PP, $\varnothing 10 \mu$, IS $<0.1$. Malar space almost linear. Genal area as broad as eye, $\mathrm{GW}: \mathrm{EW}=0.9: 0.9$, surface densely tessellate posteriorly, weakly tessellate with close PP near eye. Mesosoma: Pronotum with humeral angle and weak ridge crossed by shallow pronotal suture, surface densely tessellate. Mesoscutum with tight PP, $\varnothing 10 \mu$, IS $<0.1$, dull shagreening. Scutellum shagreening as in mesoscutum. Propodeal enclosure well defined, weakly roughened with rugulae laterally; dorsal face strongly tessellate, dull roughened. Mesepisternum densely tessellate with PP, $\varnothing 20 \mu$, IS $=1$. Middle basitarsi normal. Vein 1st $m-c u$ meeting second submarginal cell at middle of cell. Metasoma: Metasomal terga densely tessellate with crowded PP, $\varnothing 10 \mu$, IS $<0.1$; posterior depressions of terga broad, not well indicated; pygidial plate $\mathrm{V}$-shaped with internal raised triangular area. Sterna 2-5 densely tessellate with fine PP, IS $=1$ or more.

Male: BL $11.2 \mathrm{~mm}$, WL $9.4 \mathrm{~mm}(\mathrm{n}=1)$.

Color: Flagellum brown beneath; mandible reddened apically; clypeus yellowish white; lower paraocular area with small maculae; wing membranes infumate, veins and pterostigma reddish brown; tibial spurs yellowish; posterior depressions of metasomal terga black.

Pubescence: As in female, white to fulvous; tergum 1 with long hairs laterally, weak fringe apically; terga 2-4 with complete white hair bands; sterna 2-5 with white subapical fimbriae.

Structure: Head: HL/HW = 0.85. HW:MsW:MtW = $3.3: 2.7: 2.7$. Vertex densely tessellate with close and deep PP. OOD:POD:OCD $=0.76: 0.45: 0.45$. FL1 > FL2+3, FL2 < FL3 which are broader than long. Eyes with inner margins converging toward mandibles. Facial quadrangle broader than long (about $2.3: 2.0$ ). Clypeus slightly convex, surface smooth and shiny with PP, $\varnothing 20 \mu$, IS $<0.5$. CPL $=0.9 \mathrm{~mm}$. Process of labrum convex apically, truncate. Mandible bidentate, long and decussate. Lower paraocular area with PP, $\varnothing 20 \mu$, IS $<0.5$. Malar space linear. Genal area as broad as eye, GW:EW $=0.9: 0.9$, surface sculptured as in female. Mesosoma: Pronotum as in female. Mesoscutum densely tessellate anteriorly, weakly tessellate posteromedially with crowded PP, $\varnothing 20 \mu$, IS $<0.5$. Scutellum shagreening with crowded PP posteriorly. shiny with PP, $\varnothing 20 \mu$, IS $<0.5$ medially. Propodeal enclosure weakly rugulose basally, roughened apically; dorsal face strongly tessellate, dull shagreening. Mesepisternum finely tessellate, feebly shiny with PP, $\varnothing 20 \mu$, IS $<1$. Vein 1 st $m-c u$ meeting second submarginal cell before middle of cell. Metasoma: Metasomal terga weakly tessellate, shiny with crowded PP, $\varnothing 20 \mu$, IS $<0.5$; PP on terga $4-5$ slightly sparser, IS $<1$; posterior depressions of terga broad, not well indicated. Sterna $2-5$ weakly tessellate, shiny with PP, $\varnothing 20 \mu$, IS $<0.5$.

Specimens examined: China: Beijing: 2 females, Xiaolongmen, 28-30. vii. 1991 (Y.s. Shi); 2 females, Qinglong Qiao, 27. viii. 1981 (Y.-r. Wu). Hebei Province: 2 females, Yangkiaping, 10-22. vii. 1937 (O. Piel); 1 female, Mt. Xiaowutaishan, 1,200-1,400 m, 23. viii. 1964 (C.-g. Wang). Xinjiang Auton. Region: 1 female, Aletai, 1,750 m, 6. viii. 1960 (S.-y. Wang). Mongolia: Central aimak: 1 female and 4 males, Chentej aimak, 1,000-1,400 m, 28-30. vii. 1965; 1 female, Cojbalsan aimak, 600 m, 14. viii. 1965; 1 
female, Cojbalsan aimak, 14. viii. 1965; 1 male, Chovd aimak, 1,450 m, 2-3. vii. 1966; 1 male, Archangaj aimak, 21. vii. 1966; 1 female and 2 males, Tosgoni ovoo, 19-24. viii. 1967 (Z. Kaszab).

Remarks: This species is separated from the other members of Tarsandrena by the larger-sized body, the metasomal terga 1-4 with complete hair bands. Furthermore, the female has dull roughened mesoscutum with coarse PP. The male has fulvous hairs on the dorsum of thorax.

Distribution: China (new record: Beijing, Hebei Prov., Xinjiang Auton. Region); Mongolia; Russia (middle Siberia, Far East area).

Floral association: Potentilla sp.

\section{Andrena (Tarsandrena) truncatella new species}

(Fig. 1-10)

Female: BL 8.5-10.0 mm, WL 7.3-7.7 mm $(\mathrm{n}=20)$.

Color: Flagellum reddish brown beneath; mandible with apical half or less reddened; wing membranes subhyaline, moderately brown; veins and pterostigma reddish brown; tibial spurs ochraceous; posterior depressions of metasomal terga dark reddish brown.

Pubescence: Hairs on head, yellow to bright brown; those on clypeus $250 \mu$, yellow; those on vertex $250 \mu$, bright brown; those on genal area $500 \mu$, yellow; facial fovea black. Hairs on thoracic dorsum scanty; those on mesepisternum 300-500 $\mu$, yellow; propodeal corbicula well developed with simple internal hairs, fulvous; trochanteral floccus perfect, whitish, femoral floccus dense; tibial scopal hairs extremely short, reddish brown. Hairs on metasomal terga scanty; terga 2-4 with interrupted whitish hair bands; caudal fimbria bright brown; sterna 2-5 with poor-formed whitish subapical fimbriae.

Structure: Head: $\mathrm{HL} / \mathrm{HW}=0.82 . \mathrm{HW}: \mathrm{MsW}: \mathrm{MtW}=3.1: 2.9: 3.2$. Vertex roughened with coarse PP. OOD:POD:OCD $=0.6: 0.4: 0.3$. FL1 > FL2+3, FL2 subequal to FL3 which is broader than long. Eyes with inner margins subparalleled. Facial fovea broad above, narrowing to below, extending beyond a line at lower margins of antennal fossae, $\mathrm{FVL}=1.3 \mathrm{~mm}, \mathrm{FVW}=0.3 \mathrm{~mm}$. Face above antennal fossae with weak longitudinal rugulae and interrugal PP. Facial quadrangle broader than long (about $2.2: 2.0$ ). Clypeus convex medially, surface shagreening with crowded PP, $\varnothing 40 \mu$, IS $<0$.1, clypeus with obscure median impunctate ridge. $\mathrm{CPL}=1.0 \mathrm{~mm}$. Process of labrum trapezoidal, convex and truncated. Mandible tridentate. Malar space linear. Genal area as broad as eye, GW: $\mathrm{EW}=0.8: 0.8$, surface densely tessellate posteriorly, weakly tessellate with close PP near eye. Mesosoma: Pronotum with distinct humeral angle and ridge crossed by deeply depressed suture, surface weakly tessellate, shiny with fine close PP. Mesoscutum finely tessellate, feebly shiny with deep and crowded PP, $\varnothing 10-20 \mu$, IS $<0.1$. Scutellum with crowded PP, $\varnothing 20 \mu$, IS $<0.5$, feebly shiny anteriorly, weakly shagreening posteriorly. Propodeal enclosure well outlined, weakly rugulose all over, dull shagreening; dorsal face dull roughened with coarse PP. Mesepisternum weakly tessellate, shiny with obscure PP. Middle basitarsi normal. Vein 1st $m$-cu meeting second submarginal cell at middle of cell. Metasoma: Metasomal terga weakly tessellate, shiny; terga 1-4 with crowded PP, $\varnothing 10-20 \mu$, IS < 0.5; PP on terga 3-4 sparser apically; posterior depressions of terga broad, $1 / 2$ on tergum $2,2 / 3$ on terga $3-4$, well indicated; pygidial plate $\mathrm{V}$-shaped 


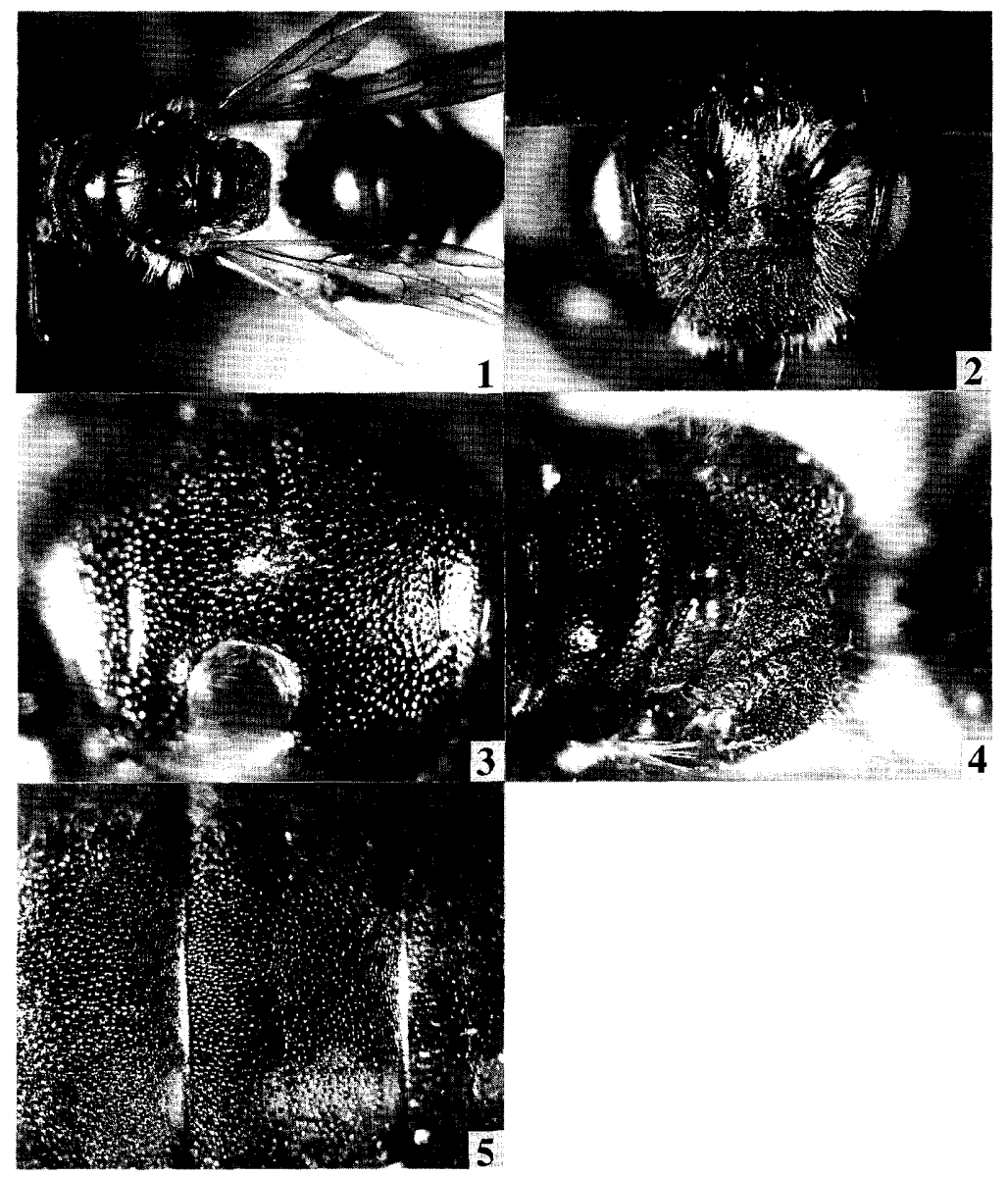

Figs. 1-5. Andrena (Tarsandrena) truncatella n. sp., female. 1: dorsal view of the whole body; 2: head in frontal view; 3: mesoscutum; 4: propodeum; 5: metasomal terga.

with raised internal area. Sterna 2-5 finely tessellate with PP, $\varnothing 10 \mu$, IS $<1$ at apical areas.

Male: BL 7.5-9.5 mm, WL 6.3-8.5 mm ( $\mathrm{n}=14)$.

Color: Flagellum reddish brown beneath except basal portion; mandible reddened apically; clypeus yellow except two brown spots laterally and black apical margin; lower paraocular area with small yellow maculae, occasionally lacking; wing membranes infumate, veins and pterostigma reddish brown; tibial spurs yellowish; posterior depressions of metasomal terga yellowish brown.

Pubescence: Hairs on head and thorax sparse, fulvous; those on clypeus $500 \mu$; those on vertex $300-500 \mu$; those on mesoscutum $500 \mu$; those on scutellum and propodeum $700 \mu$; those on mesepisternum $800 \mu$, dense. Hairs on metasomal terga extremely short and sparse, yellowish to brown; terga 2-5 with weak apical fringes laterally; sterna 2-5 with yellowish subapical fimbriae. 


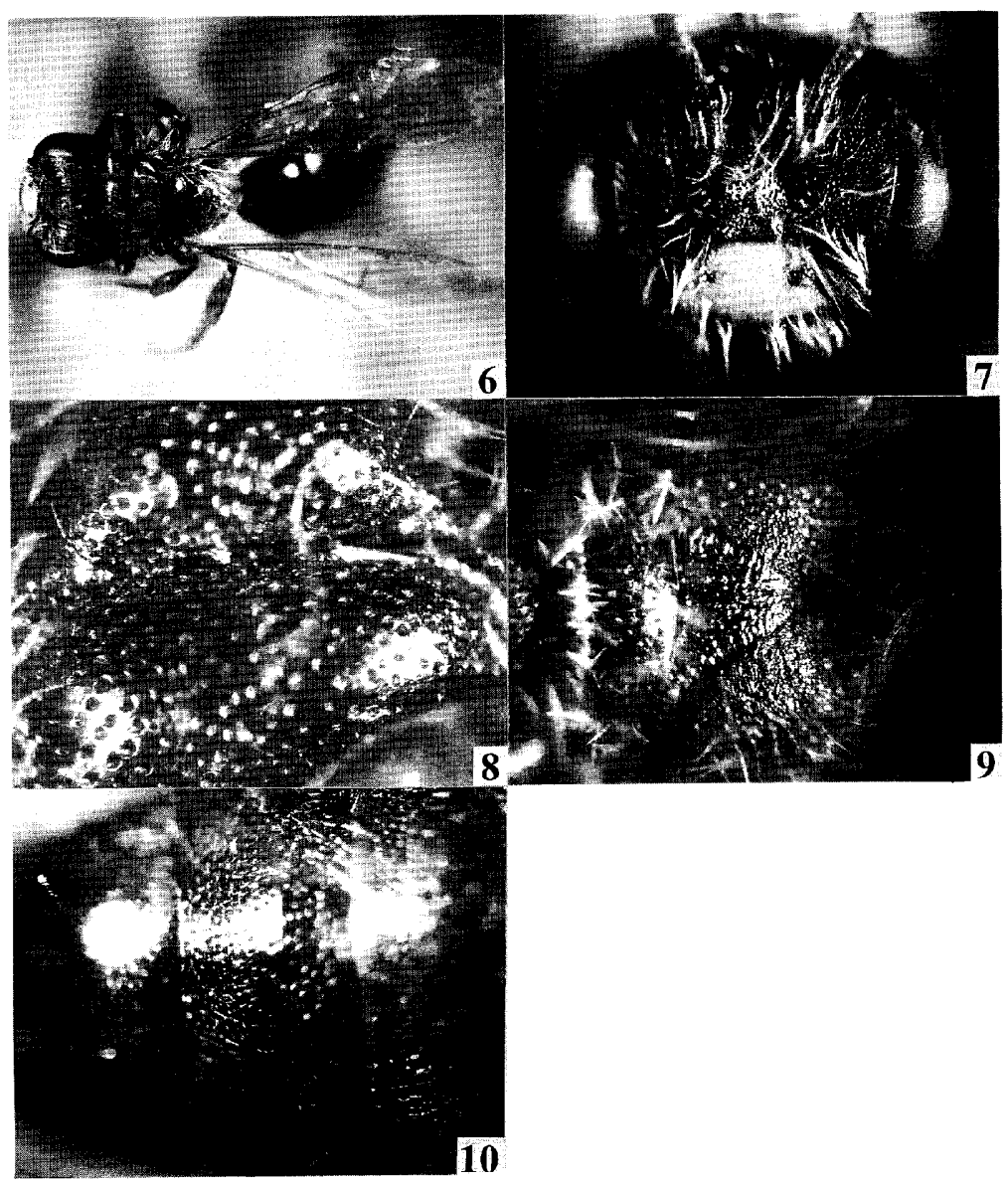

Figs. 6-10. Andrena (Tarsandrena) truncatella n. sp., male. 6: dorsal view of the whole body; 7: head in frontal view; 8: mesoscutum; 9: propodeum; 10: metasomal terga.

Structure: Head: HL/HW = 0.74. HW:MsW:MtW = 3.1 : $2.5: 2.5$. Vertex, face above antennal fossae and clypeus sculptured as in female except clypeus shiny with PP, $\varnothing 20 \mu$, IS < 0.5. OOD:POD:OCD $=0.7: 0.4: 0.4$. FL1 > FL2+3, FL2 subequal to FL3 which is broader than long. Eyes with inner margins converging toward mandibles. Facial quadrangle broader than long (about $1.7: 1.5$ ). Clypeus smooth and shiny with shallow, obscurc PP, CPL $=0.8 \mathrm{~mm}$. Process of labrum convex apically, truncate. Mandible bidentate, long and decussate. Lower paraocular area feebly shiny with crowded PP, $\varnothing 20 \mu$, IS < 0.1. Malar space linear. Genal area slightly broader than eye, $\mathrm{GW}: \mathrm{EW}=0.9: 0.8$, surface sculptured as in female. Mesosoma: Pronotum with distinct humeral angle and ridge, which crossed by deeply depressed sutures, surface weakly tessellate, shiny with close PP. Mesoscutum weakly tessellate, shiny with crowded PP, $\emptyset 20 \mu$, IS $<0.5$. Scutellum sculptured as in mesoscutum. Propodeum roughened as in 
female. Mesepisternum densely tessellate with obscure PP. Wing venation as in female. Metasoma: Metasomal terga rather weakly tessellate, shiny; tergum 1 with PP, $\varnothing 10-20 \mu$, IS $<1$; terga 2-4 with PP, $\varnothing 10 \mu$, IS $=1-2$ at basal areas, sparser apically; posterior depressions of terga broad, not well indicated. Sterna 2-5 weakly tessellate, shiny with close PP.

Type material: Holotype female, Xiaolongmen, 700 m, Beijing, China, 28. vii. 1995 (H.-1. Xu); Paratypes: China: Beijing: 9 females and 12 males, same locality, date and collector as the holotype. Hebei Province: 2 females, Mt. Guangtu, Pingquan County, 1,250 m, 31. vii. 1985 (X.-z. Zhang). Jilin Province: 7 females, Mt. Changbeishan, Beihe, 26. vii.-7. viii. 1981 (Y.-r. Wu). Liaoning Province: 5 females and 1 male, Kaolin-tze, 1. vii. 1939 (M. Volkoff). Heilongjiang Province: 3 females and 1 male, Mt. Daxinganling, 18. vii. 1970.

Remarks: This species is similar to Andrena bonivuri Osytshnjuk in having the facial fovea narrowing below in female. The female can be separated from that of bonivuri by the clypeus closely punctate and the metasomal terga with close PP. The male can be separated from that of bonivuri by the genital capsule with gonostylus narrow.

Distribution: China (Beijing, Hebei, Jilin, Heilongjiang Provs.).

Floral associations: Potentilla spp.

\section{Andrena (Tarsandrena) shawanensis new species}

(Fig. 11-20)

Female: BL $10.5 \mathrm{~mm}$, WL $8.7 \mathrm{~mm}(\mathrm{n}=1)$.

Color: Flagellum reddish brown beneath; mandible with apical half reddened; wing membranes subhyaline, weakly brown, veins and pterostigma reddish yellow; tibial spurs yellow; posterior depressions of metasomal terga dark brown.

Pubescence: Hairs on head and thorax dense, white to black; those on clypeus $600 \mu$. whitish; those on antennal area whitish; those on vertex $400-750 \mu$, dull white mixed with black; those on genal area $500 \mu$, whitish; facial fovea dark brown. Hairs on mesoscutum $300-500 \mu$, dull white anteriorly, black medially and posteriorly; those on scutellum black mixed with dull white; propodeal corbicula white with a little brown, with simple internal hairs; trochanteral floccus perfect, white; femoral floccus dense; tibial scopal hairs extremely short, whitish yellow. Hairs on metasomal terga scanty; tergum I with long white hairs laterally; terga 2-4 with complete white hair bands; caudal fimbria brown medially, whitish laterally; sterna $2-5$ with white subapical fimbriae.

Structure: Head: $\mathrm{HL} / \mathrm{HW}=0.76$. HW:MsW:MtW $=3.4: 3.0: 3.4$. Vertex weakly shagreening with crowded PP. OOD:POD:OCD $=0.6: 0.5: 0.25$. FL1 > FL2 +3, FL2 $=$ FL3 which are broader than long. Eyes with inner margins paralleled. Facial fovea extending below a line at lower margins of antennal fossae, $\mathrm{FVL}=1.2 \mathrm{~mm}, \mathrm{FVW}=0.4$ $\mathrm{mm}$. Face above antennal fossae with longitudinal rugulae, interrugal space with coarse PP, dull shagreening. Facial quadrangle quadrate (about $2.4: 2.4$ ). Clypeus slightly convex, surface weakly tessellate, shiny with crowded PP, $\varnothing 20-40 \mu$, IS $<0.1$. $\mathrm{CPL}=1.1 \mathrm{~mm}$. Process of labrum large with truncated area shiny. Mandible tridentate. 


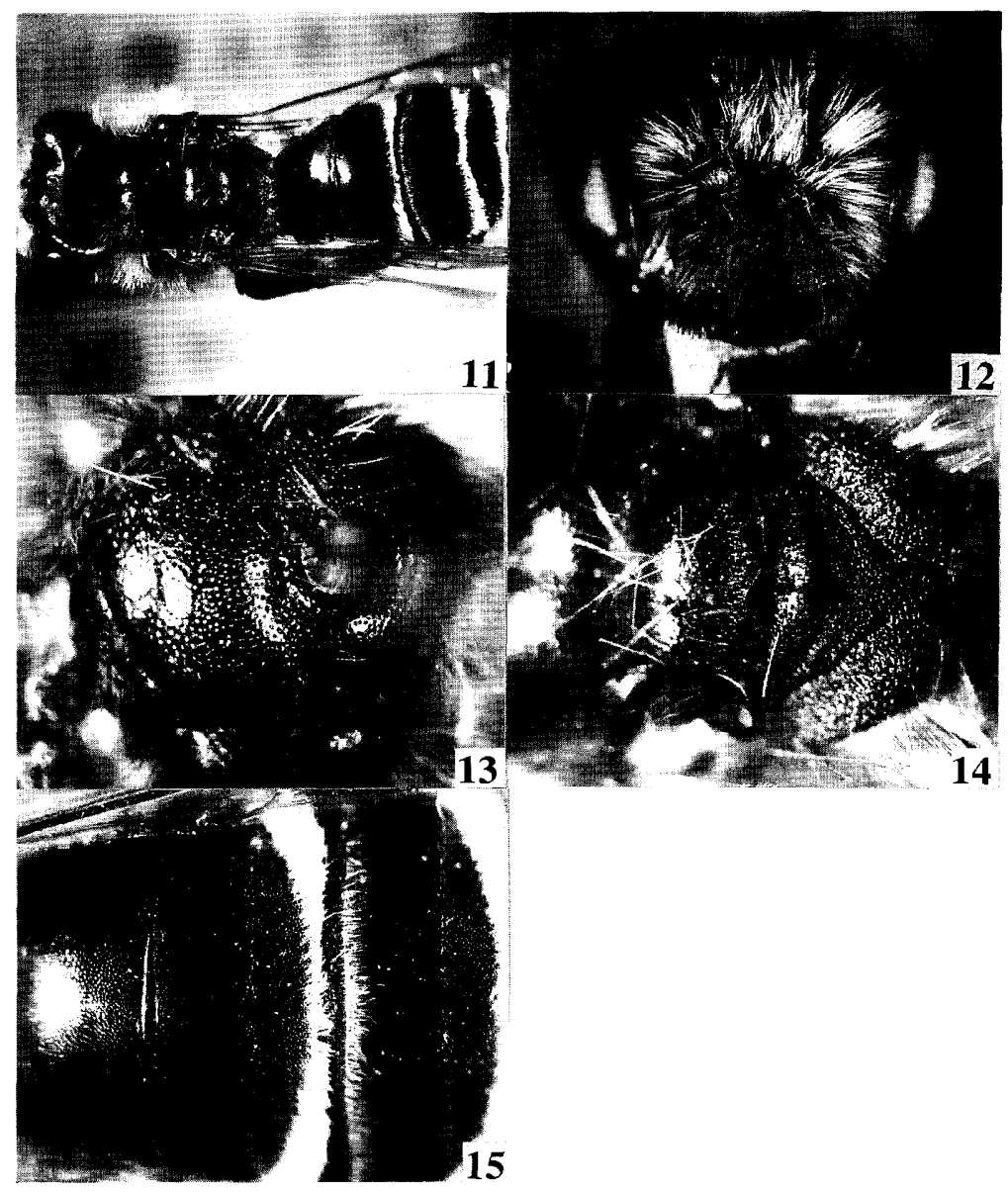

Figs.11-15. Andrena (Tarsandrena) shawanensis n. sp., female. 11: dorsal view of the whole body; 12: head in frontal view; 13: mesoscutum; 14: propodeum; 15: metasomal terga.

Lower paraocular area weakly tessellate with crowded minute PP. Malar space linear. Genal area slightly broader than eye, GW:EW $=0.9: 0.8$, surface finely tessellate posteriorly, weakly tessellate with crowded PP near eye. Mesosoma: Pronotum with humeral angle and ridge, surface densely tessellate. Mesoscutum weakly tessellate, surface shiny with crowded PP, $\varnothing 10-20 \mu$, IS $<0.5$. Scutellum with PP, $\varnothing 10 \mu$, IS $<0.1$. Propodeal enclosure well defined, finely rugulose laterally, roughened; dorsal face outlined by deep sutures, dull shagreening. Mesepisternum finely tessellate with obscure PP. Vein 1 st $m-c u$ meeting second submarginal cell at middle of cell. Metasoma: Metasomal terga weakly tessellate, feebly shiny with close PP, $\varnothing 10 \mu$, IS $<1$; pos-terior depressions of terga broad, well indicated; pygidial plate $\mathrm{V}$-shaped with raised triangular area. Sterna 2-5 finely tessellate, impunctate basally.

Male: BL $6.5 \mathrm{~mm}$, WL $5.5 \mathrm{~mm}(\mathrm{n}=1)$. 


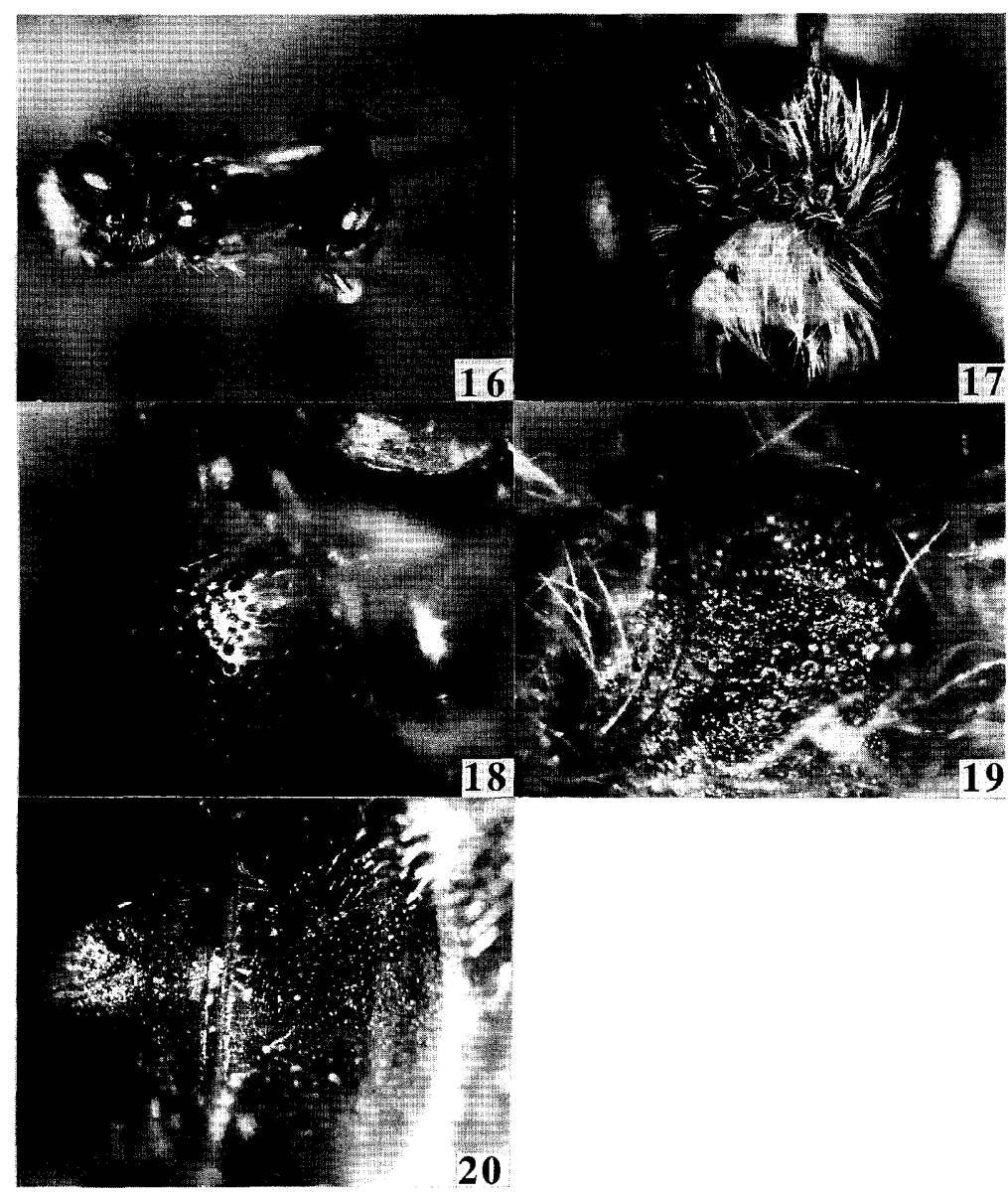

Figs.16-20. Andrena (Tarsandrena) shawanensis n. sp., male. 16: dorsal view of the whole body; 17: head in frontal view; 18: mesoscutum; 19: propodeum; 20: metasomal terga.

Color: Flagellum reddish brown beneath; mandible with apical half reddened; clypeus yellowish white except two brown spots laterally; wing membranes infumate, veins and pterostigma reddish yellow; tibial spurs ochraceous; posterior depressions of metasomal terga yellowish brown.

Pubescence: Hairs on head and thorax dense, white without black except mesoscutum scanty; terga 2-4 with short, bright brown; apical area with interrupted white hair bands; sterna 2-5 with whitish subapical fimbriae.

Structure: Head: HL/HW = 0.74. HW:MsW:MtW = $2.3: 1.9: 2.0$. Vertex weakly tessellate with close PP. OOD:POD:OCD $=0.5: 0.3: 0.15$. FL1 > FL2+3, FL2 < FL3 broader than long. Eyes with inner margins slightly converging toward mandibles. Face above antennal fossae with distinct longitudinal rugulae, interrugal PP small, obscure. Facial quadrangle about quadrate (about $1.5: 1.5$ ). Clypeus weakly convex, surface smooth and shiny with shallow PP, $\varnothing 10 \mu$, IS $<1$, CPL $=0.7 \mathrm{~mm}$. Process of labrum 
as in female, but smaller. Mandible bidentate, long and decussate. Lower paraocular area weakly tessellate and shiny with crowded PP, $\varnothing 10 \mu$, IS $<0.5$. Malar space linear. Genal area as broad as eye, $\mathrm{GW}: \mathrm{EW}=0.7: 0.7$, surface finely tessellate posteriorly, weakly tessellate, shiny with close PP near eye. Mesosoma: Pronotum with humeral angle and weak ridge, which crossed by slightly depressed sutures, surface densely tessellate. Mesoscutum weakly tessellate, shiny with crowded PP, Ø 10-20 $\mu$, IS $<0.5$. Scutellum sculptured as in mesoscutum. Propodeal enclosure well defined, sculptured by longitudinal rugulae; dorsal face of propodeum dull shagreening. Mesepisternum finely tessellate with obscure PP. Vein 1st $m$ - $c u$ meeting second submarginal cell before middle of cell. Metasoma: Metasomal terga weakly tessellate, shiny with close microscopic PP, IS < 1; posterior depressions of terga not well indicated. Sterna 2-5 finely tessellate with microscopic PP basally.

Type material: Holotype female, Shawan, 2,700 m, Xinjiang Auton. Region. China, 22. vii. 1957 (G. Wang); Paratype: China: Xinjiang Auton. Region: 1 male, Aheqi, 2,010 m, 19. vii. 1959 (G. Wang).

Remarks: This species is similar to Andrena angarensis Cockerell. The female is easily separated from that of angarensis by the clypeus crowdedly punctate and the propodeal enclosure weakly shagreening, not granulate.

Distribution: China (Xinjiang Auton. Region).

Floral association: Not available.

\section{Andrena (Tarsandrena) tarsata baicalensis Cockerell}

Andrena baicalensis Cockerell, 1929, Ann. Mag. Nat. Hist., (10) 3: 395 [female, Siberia].

Andrena (Tarsandrena) tarsata: Osytshnjuk, 1984, Vestn. Zool., (2): 26 [female \& male, in key]; Osytshnjuk, 1995, Key Ins. Rus.Far East Six Vol., 4 (1): 512, 517 [female \& male, in key].

Andrena (Tarsandrena) tarsata baicalensis: Tadauchi \& Xu, 1999, Esakia, (39): 23-24

[female, redescription of syntype].

Specimens examined: China: Sichuan: 1 female, Zhongreniao, Xiangcheng County, 3,800 m, 2. vii. 1982 (X.-z. Zhang). Xizang Auton. Region: 1 female, Jietang, Caya County, 11. vii. 1976 (Y.-h. Han).

Remarks: This species is similar to Andrena shawanensis n. sp. in female by having the tridentate mandible and the normal facial fovea. The female can be recognized by the clypeus more shagreening, the metasomal terga with weak and sparser PP. The male can be separated from that of shawanensis by the metasomal terga sparsely punctate.

Distribution: China (new record: Xizang Auton. Region, Sichuan Prov.); Mongolia: Russia (Siberia, Far East area).

Floral association: Not available.

5. Andrena (Tarsandrena) niveimonticola new species

(Fig. 21-30)

Female: BL 7.0-8.2 mm, WL 5.7-6.7 mm $(\mathrm{n}=20)$. 
Color: Flagellum reddish brown beneath; mandible with apical third or less reddened; wing membranes subhyaline, weakly brown, veins and pterostigma reddish brown; tibial spurs reddish yellow; posterior depressions of metasomal terga dark reddish brown.

Pubescence: Hairs on head and thorax sparse, whitish to black; those on clypeus $300 \mu$, whitish; those on antennal area dense, black; those on vertex $200-400 \mu$, whitish mixed with brown; those on genal area whitish mixed with black; facial fovea brown. Hairs on mesoscutum rather sparse, $300 \mu$, black; those on scutellum scanty; those on mesepisternum $600 \mu$; whitish below, whitish mixed with brown above; propodeal corbicula dull white with simple internal hairs; trochanteral floccus nearly perfect, white; femoral floccus dense; tibial scopal hairs extremely short, bright brown. Hairs on metasomal terga scanty; terga 2-4 with sparse apical hair bands laterally, white: caudal

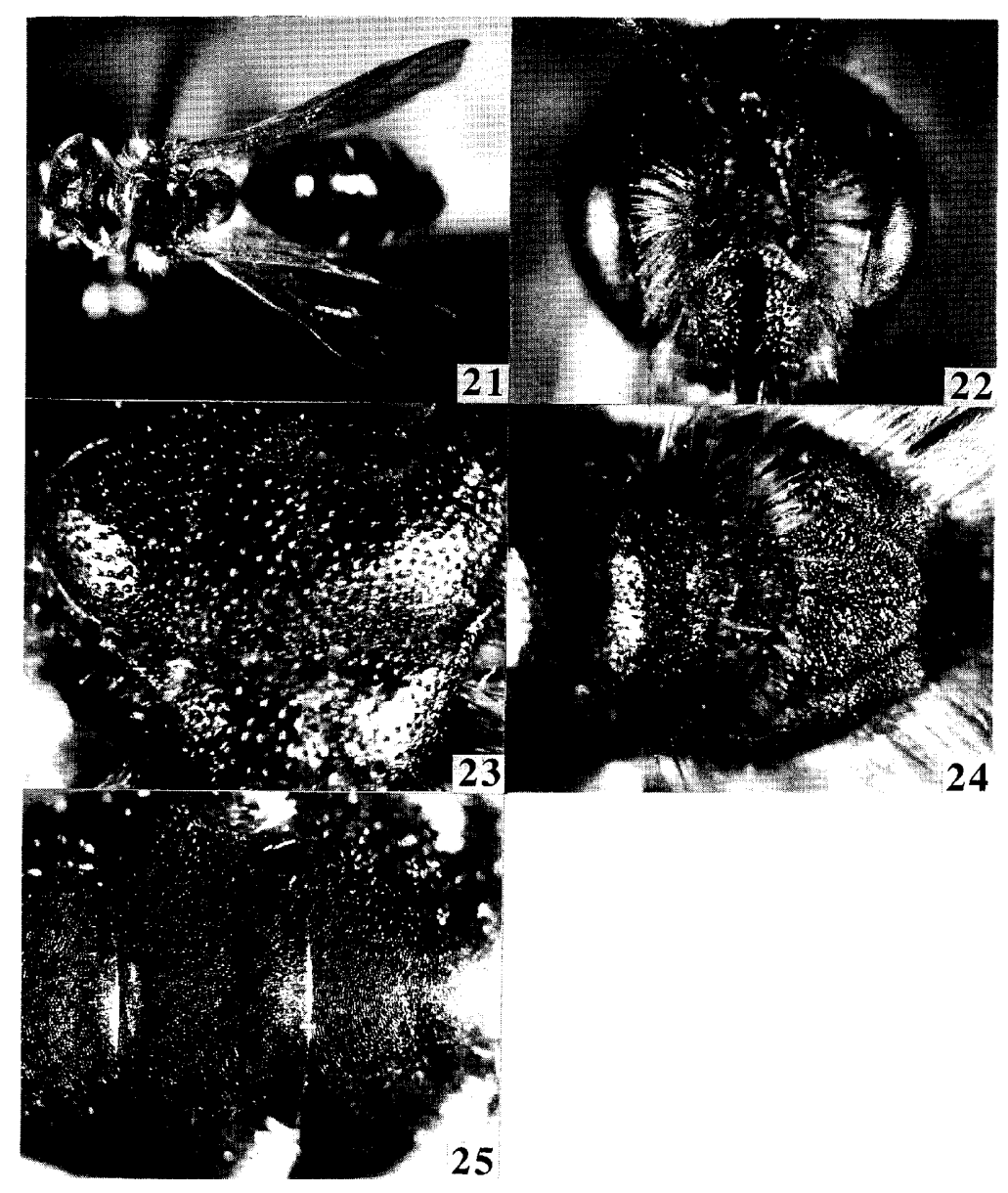

Figs. 21-25. Andrena (Tarsandrena) niveimonticola n. sp., female. 21: dorsal view of the whole body; 22: head in frontal view; 23: mesoscutum; 24: propodeum; 25: metasomal terga. 
fimbria brown; sterna 2-4 with white subapical fimbriae; sternum 5 with bright brown hairs.

Structure: Head: HL/HW = 0.86. HW:MsW:MtW $=2.2: 2.2: 2.2$. Vertex densely tessellate with obscure PP. OOD:POD:OCD $=0.4: 0.3: 0.2$ FL1 > FL2 +3, FL2 = FL3 with broader than long. Eyes with inner margins subparalleled. Facial fovea narrow, extending below a line at lower margins of antennal fossae, $F V L=0.8 \mathrm{~mm}, F V W=0.2$ $\mathrm{mm}$. Face above antennal fossae with fine longitudinal rugulac, interrugal PP obscure, dull shagreening. Facial quadrangle quadrate (about 1.6:1.6). Clypeus slightly convex, weakly tessellate medially, shiny with broad median impunctate space, densely tessellate laterally with PP, $\varnothing 20 \mu$, IS $<1, \mathrm{CPL}=0.8 \mathrm{~mm}$. Process of labrum quadrate, weakly truncate. Mandible bidentate. Lower paraocular area densely tessellate with obscure PP. Malar space linear. Genal area slightly broader than eye, $\mathrm{GW}$ : $\mathrm{EW}=0.6: 0.5$, surface

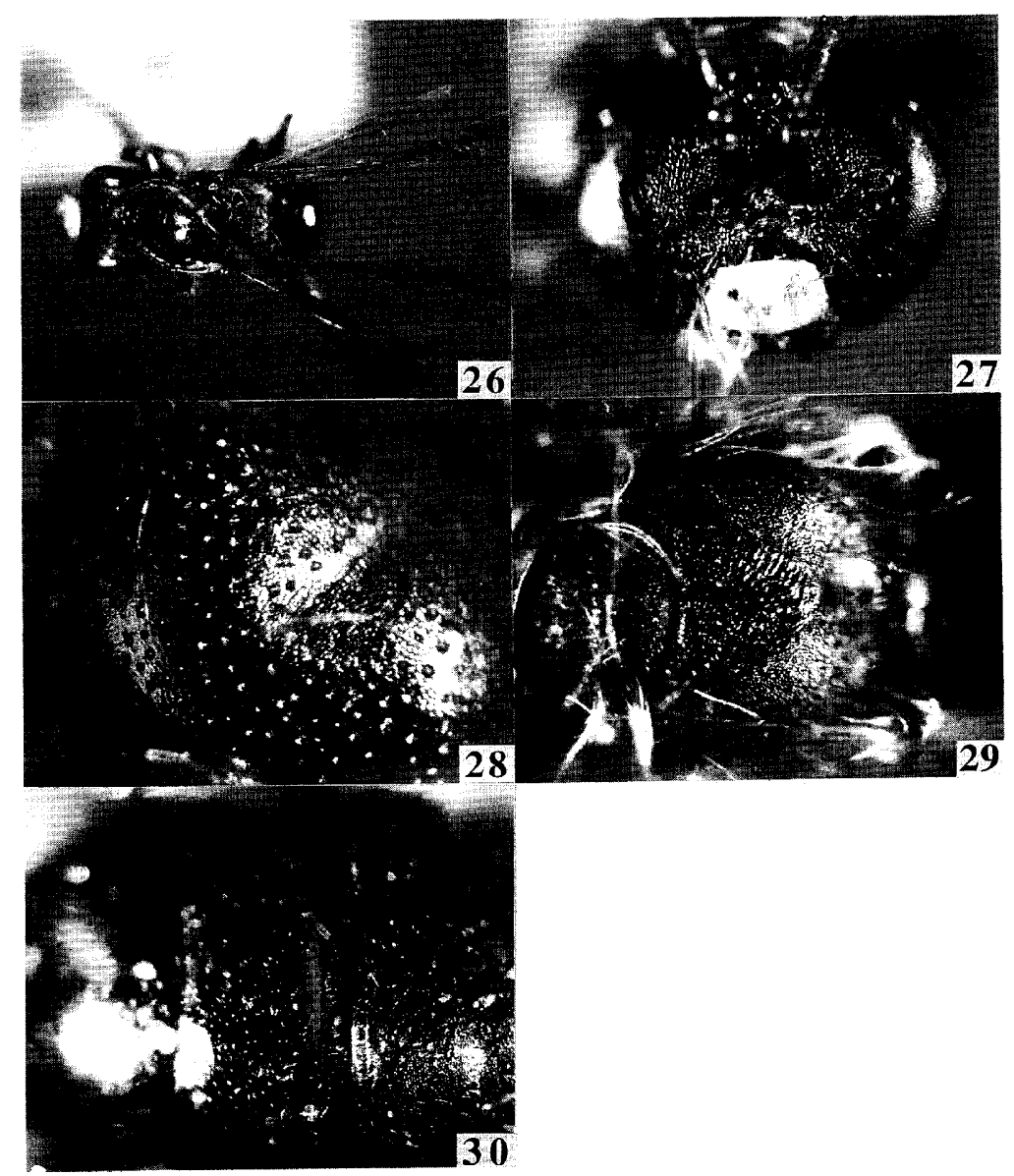

Figs. 26-30. Andrena (Tarsandrena) niveimonticola n. sp., male. 26: dorsal view of the whole body; 27: head in frontal view; 28: mesoscutum; 29: propodeum; 30: metasomal terga. 
densely tessellate. Mesosoma: Pronotum without humeral angle and ridge, surface finely tessellate, feebly shiny. Mesoscutum densely tessellate anteriorly and posteriorly, weakly tessellate with microscopic PP, IS < 1 or obscure. Scutellum sculptured as in mesoscutum. Propodeum flat, propodeal enclosure not well defined, dull shagreening with longitudinal rugulae basally; dorsal face of propodeum densely tessellate with obscure PP. Mesepisternum densely tessellate. Vein 1 st $m$-cu meeting second submarginal cell near end of cell. Metasoma: Metasomal terga finely tessellate, feebly shiny; terga 1-4 with microscopic PP, irregular in distribution; posterior depressions of terga weak, not well indicated; pygidial plate $\mathrm{V}$-shaped with round apex and raised triangular area. Sternum 2 finely tessellate with close minute PP apically: sterna 3-5 smooth and shiny basally without PP, finely tessellate with close PP apically.

Male: BL 6.5-7.0 mm, WL 6.0-6.6 mm $(\mathrm{n}=2)$.

Color: Flagellum reddish brown beneath; mandible reddened apically; clypeus yellowish white except two brown spots laterally; wing membranes infumate. paler at apex, veins and pterostigma reddish brown; tibial spurs yellow; posterior depressions of metasomal terga yellowish brown.

Pubescence: Hairs on head and thorax sparse, white to black; those on clypeus $600 \mu$, white; those on antennal area black; those on vertex $300-750 \mu$, white mixed with brown; those on genal area white mixed with black; those on mesoscutum $700 \mu$, white: those on scutellum 400-600 $\mu$; those on mesepisternum $700 \mu$, white; those on metasomal terga scanty; terga 2-4 with weak apical fringes laterally; sterna 2-5 with weak whitish subapical fimbriae.

Structure: Head: HL/HW = 0.78. HW:MsW:MtW $=2.2: 2.0: 2.0$. Vertex densely tessellate. OOD:POD:OCD $=0.5: 0.3: 0.2$. FL1 = FL2+3, FL2 = FL3 broader than long. Eyes with inner margins slightly converging toward mandibles. Face above antennal fossae with longitudinal rugulae, interrugal PP coarse, dull roughened. Facial quadrangle about quadrate (about $1.5: 1.5$ ). Clypeus slightly convex, surface smooth and shiny with shallow PP, $\varnothing 10 \mu$, IS $<0.5$ laterally, sparser medially, CPL $=0.5 \mathrm{~mm}$. Process of labrum truncate with apex emarginate. Mandible bidentate, slightly decussate. Lower paraocular area dull shagreening with coarse PP. Malar space linear. Genal area as broad as eye, $\mathrm{GW}: \mathrm{EW}=0.6: 0.6$, surface weakly rugulose. Mesosoma: Pronotum without humeral angle and ridge, surface sculptured as in female. Mesoscutum weakly tessellate, shiny with crowded PP, $\varnothing 10-20 \mu$, IS $<0.5$. Scutellum densely tessellate anteriorly, weakly tessellate with PP, $\varnothing 10 \mu$, IS $=1$ medially and posteriorly. Mesepisternum densely tessellate with irregular PP. Propodeal enclosure well defined by lateral sutures, sculptured by longitudinal rugulae all over; dorsal face of propodeum densely tessellate as in the members of Oreomelissa. Mesepisternum strongly tessellate with obscure PP. Vein 1st $m-c u$ meeting second submarginal cell near end of cell. Metasoma: Metasomal terga smooth to weakly tessellate, shiny; terga 1-4 with weak, sparse microscopic PP, IS = 1-3; posterior depressions of terga not well indicated. Sterna 2-5 weakly tessellate, shiny with microscopic PP, IS = 1-2 apically.

Type material: Holotype female, Zhongdian, 3,250 m, Yunnan Province, China, 3. viii. 1981 (X.-z. Zhang); Paratypes: China: Yunnan Province: 2 females, same locality, date and collector as the holotype; 1 female, Mt. Baimang Snow, Deqing County, 3,700 m, 25. viii. 1981 (S.-y. Wang); 1 female, Ludian, Lijiang, 2,800 m, 11. viii. 1984 (J.-g. 
Fan); 7 females, Lidiping, Weixi, 3,300 m, 13-14. viii. 1984 (J.-g. Fan); 4 females, Zhongdian, 2,900 m, 7. viii. 1984 (J.-g. Fan); 2 females, Geza, Zhongdian, 3,250 m, 6. viii. 1981 (X.-z. Zhang); 1 male, Geza, Zhongdian, 3,150 m, 2. viii. 1984 (S.-b. Liao); 1 female and 1 male, Xiaozhongdian, 3,200 m, 2. viii. 1984 (J.-g. Fan). Xizang Auton. Region: 1 female, Jiangda, 3,400 m, 24. vii. 1876 (Y.-h. Han); 2 females, Leiwuqi, 3,750 m, 21-25. viii. 1976 (X.-z. Zhang).

Remarks: This species differs from the other members of Tarsandrena by the pronotum without humeral angle and ridge, the dorsal propodeal face densely tessellate, not roughened as the members of Oreomelissa, the metasomal terga with scattered microscopic PP.

Variety: Specimens collected in Zhongdian, Yunnan Province, have the more shagreening clypeus laterally, and the more distinct PP on the mesoscutum.

Distribution: China (Xizang Auton. Region, Yunnan Prov.).

Floral association: Potentilla sp.

\section{Andrena (Tarsandrena) angarensis Cockerell}

Andrena angarensis Cockerell, 1929, Ann. Mag. nat. Hist., (10)3: 394-395 [female \& male, mid Siberia].

Andrena (Tarsandrena) angarensis: Osytshnjuk, 1984, Vestn. Zool., (2): 25, 26 [female \& male, in key]; Osytshnjuk, 1995, Key Ins. Rus. Far East Six Vol., 4 (1): 512, 517 [female \& male, in key]; Tadauchi \& Xu, 1999, Esakia, (39): 26-28 [female, redescription of type].

Male (redescription): BL $7.5 \mathrm{~mm}$, WL $5.5 \mathrm{~mm}(\mathrm{n}=4)$.

Color: Flagellum reddish brown beneath; mandible with apical third reddened; clypeus yellowish white except two brown spots laterally; lower paraocular area yellowish white all over; wing membranes infumate, veins and pterostigma reddish brown; tibial spurs yellow; posterior depressions of metasomal terga yellowish brown.

Pubescence: Hairs on head as in female, white; mesoscutum and scutellum with relatively dense hairs, dull white; terga 2-4 with broadly interrupted white hair bands; sterna 2-5 with weak dense whitish hairs, subapical fimbriae not obvious.

Structure: Head: HL/HW = 0.72. HW:MsW:MtW $=2.5: 2.3: 2.3$. Vertex densely tessellate. OOD:POD:OCD $=0.5: 0.4: 0.2$. FL1 $=$ FL2 +3 , FL2 < FL3 broader than long. Eyes with inner margins slightly converging toward mandibles. Face above antennal fossae with longitudinal rugulae, interrugal PP coarse, dull shagreening. Facial quadrangle quadrate (about $1.5: 1.5$ ). Clypeus slightly convex, surface smooth and shiny with shallow PP, $\varnothing 20 \mu$, IS $<0.5, \mathrm{CPL}=0.8 \mathrm{~mm}$. Process of labrum truncate with apex deeply emarginate. Mandible bidentate and decussate. Lower paraocular area as in clypeus. Malar space linear. Genal area as broad as eye, GW:EW $=0.75: 0.75$, surface densely tessellate with close PP. Mesosoma: Pronotum sculptured as in female. Mesoscutum densely tessellate anteriorly, weakly tessellate posteromedially, feebly shiny with crowded PP, $\varnothing 20 \mu$, IS $<0.5$. Scutellum weakly shagreening with coarse PP. Propodeal enclosure rugulose; dorsal face densely tessellate, shagreening. Mesepisternum as in female, but PP coarser. Vein 1 st $m-c u$ meeting second submarginal 
cell at middle of cell. Metasoma: Metasomal terga sculptured as in female; terga 1-4 with tight PP; posterior depressions of terga broad on terga 3-5, narrow on tergum 2, well indicated. Sterna 2-5 weakly tessellate, impunctate apically.

Specimens examined: China: Heilongjiang Province: 1 female, Harbin, 15. viii. 1954. Mongolia: 1 female and 1 male, Chentej aimak, 1,400 m, 27-28. vii. 1965 (Z. Kaszab); 1 male, Chentej aimak, 1,000 m, 30. vii. 1966 (Z. Kaszab); 3 females and 1 male, Archangaj aimak, 1,500 m, 21-22. vii. 1966 (Z. Kaszab); 1 male, Suchebaator aimak, 950 m, 9. viii. 1965 (Z. Kaszab).

Remarks: This species is similar to Andrena tarsata baicalensis Cockerell. The female can be separated from that of tarsata baicalensis by the mandible bidentate and the clypeus without median impunctate line. The male can be separated from that of tarsata baicalensis by the lower paraocular area with larger maculae and the metasomal terga with close punctures.

Distribution: China (new record: Heilongjiang Prov.); Mongolia (Archangaj. Chentej, Suchebaator); Russia (mid Siberia and Far East area).

Floral association: Not available.

\section{Acknowledgements}

We would like to appreciate Dr. Y.-r. Wu of Institute of Zoology. Chinese Academy of Sciences, the late Dr. Z. Kaszab of Hungary for lending useful material for this study and Prof. Emeritus Y. Hirashima and Prof. J. Yukawa of Kyushu University for their varoius help. We also thank Dr. A. Z. Osytshnjuk of the Institute of Zoology, Ukrainian Academy of Sciences, Kiev for sending her reprints and Dr. K. Pesenko of the Institute of Zoology, Russian Academy of Sciences, St. Petersburg, for giving us important comments on the type of Andrena ehnbergi Morawitz.

\section{References}

Osytshnjuk, A. Z., 1984. New Paleaectic subgenus and new species of the genus Andrena F. (Hymenoptera, Andrenidae). Vestn. Zool., (2): 23-30. (In Russian with English summary)

Osytshnjuk, A. Z., 1995. Apoidea, In Lehr, P. A. (ed.) Key to the Insects of Russian Far East in Six Volumes Vol. IV. Part 2, St. Petersburg: Nauka, 606pp.

Warncke, K. 1968. Die Untergattungen der westpaläarktischen Bienengattung Andrena F. Mem. Est. Mus. Zool. Univ. Coimbra, (307): 1-107. 